\title{
THE EFFECTS OF WILDLIFE UNGULATE HERBIVORY UPON RIPARIAN AND STREAM ECOSYSTEMS WITHIN THE GREATER YELLOWSTONE AREA
}

\author{
DAVID TRAVERS $\downarrow$ PETER MEIER \\ DEPARTMENT OF ENVIRONMENTAL AND INDUSTRIAL HEALTH \\ UNIVERSITY OF MICHIGAN $\downarrow$ ANN ARBOR
}

\begin{abstract}
$\downarrow \quad$ ABSTRACT
This study will investigate the effects of wildlife ungulate herbivory, principally of elk and moose, upon riparian and stream habitats within the Greater Yellowstone Ecosystem, which encompasses both the Grand Teton National Park and the Yellowstone National Park. The emphasis of the research will concern how these effects express themselves within the aquatic macroinvertebrate community. Sampling conducted in August and October of 1996 revealed that sites subject to moderate and minimal herbivore use contain greater quantities of allochthonous material and a more diverse macroinvertebrate trophic structure than streams incurring heavy herbivore use.
\end{abstract}

\section{$\downarrow \quad$ INTRODUCTION}

That wildlife herbivory exerts some influence within the Greater Yellowstone Ecosystem finds at least ostensible support by simply driving through the area and observing any of the several exclosures which have been established within the parks. The relatively dense presence of, for instance, willow and aspen shrubs within these exclosures stands in marked contrast to the often complete absence of such vegetation immediately outside of the exclosures. Where shrubs still persist outside the exclosures, herbivory has reduced significantly their cover and height. For willows in particular, one study in Yellowstone has shown that shrubs within the exclosures possess mostly adult branches, whereas outside the exclosures shoots exist largely in the juvenile stage, though the author concludes that willows may be subject to long periods of severe browsing without being eliminated from an area (Despain 1989). Similarly, within the Grand Teton Park, a report recently completed by the University of Wyoming, found that several areas along the Snake River have incurred losses of vegetative cover as a consequence of browsing, most notably by elk and moose during the winter months (Smith et. al. 1994).

This study will test the general hypothesis that the effects of wildlife herbivory within riparian areas will alter the species composition and trophic structure of the aquatic macroinvertebrate community. For the sake of clarity it may be helpful to organize the various hypotheses to be tested into four broad categories:

$\mathrm{H}_{0} 1$ : Riparian conditions do not differ significantly among sites subject to different intensities of herbivore use. Individual null hypotheses include tests comparing streambank stability, forage utilization, canopy cover, and insulation.

$\mathrm{H}_{0}$ 2: Stream substrate conditions do not differ significantly among sites subject to different 
intensities of herbivore use. Null hypotheses include comparisons of substrate composition, velocity, degree of embeddedness, periphyton (AFDM and chlorophyll $a$ ), and benthic organic matter.

$\mathrm{H}_{0} 3$ : Stream water quality variables do not differ significantly among sites subject to different intensities of herbivore use. Null hypotheses include comparisons of alkalinity, hardness, DO, temperature, TSS, chlorophyll $a$, nutrients (N and $P)$, and sulfate.

$\mathrm{H}_{0} 4$ : Macroinvertebrate communities do not differ among sites subject to different intensities of herbivore use. Null hypotheses include comparisons of density of collective and individual taxa, richness, evenness, biotic indices (e.g., Tolerance Quotient, Shannon-Weaver), and the relative proportions and densities of functional feeding groups.

These hypotheses have been selected on the grounds that previous studies have shown a relationship between some of these environmental variables and either herbivory or the macroinvertebrate community. From a review of this literature, there appear to be at least four principal mechanisms by which the effects of herbivory might influence the aquatic insect community. First, with the reduction or elimination of riparian canopy, a stream receives greater quantities of light which may translate into higher primary and secondary productivity (Murphy et. al. 1981, Hawkins et. al. 1982, Wesche 1987, Li et. al. 1994) and larger temperature fluctuations, the latter of which may induce physiological stress in some macroinvertebrates (Bisson and Davis 1976, DeWalt and Stewart 1995). Second, the removal of riparian vegetation and the compaction of soil may result in higher sediment loads which may alter the inhabitability of substratum by affecting water movement, food quantity and quality, oxygen availability, and interstitial spacing (Minshall 1984, Lenat et. al. 1981). Third, the reduction in canopy, accompanied perhaps by a shift in species composition of the riparian vegetation, will affect the quantity and variety of allochthonous material which, in turn, may change the trophic structure of stream biota. Scrapers, for instance, may replace shredders as the predominant functional feeding group (Minshall 1983, Dudgeon 1988, though see Murphy et. al. 1981). Finally, aside from the effects associated with the removal of vegetation, the activity of herbivores in riparian areas may influence stream ecosystems through the deposition of wastes and the trampling of stream banks (Myers and Swanson 1995). Among other consequences, this may reduce velocity and thus render the stream less or more hospitable for certain insect species (Minshall and Minshall 1977).

The purpose of this study will be to identify the effects of wildlife ungulate grazing on the aquatic macroinvertebrate community directly through the use of diversity indices and indirectly through the measurement of some of the environmental factors which may influence the insect population. The study methods, therefore, have been designed such that some sort of relationship can be established among the environmental variables, the macroinvertebrate community structure, and wildife herbivory. fivefold:

The significance of the proposed work is

i) Though aquatic insects have been collected on a fairly regular basis within certain streams of the Greater Yellowstone area, the information which could be gleaned from these samples seems perhaps inaccessible to park officials, most of whom are not entomologists. Further, there have been few attempts to correlate the species diversity and trophic organization of the insect communities to the environmental conditions, such as herbivore use, of the streams from which the samples were collected. The data from this work thus will improve our understanding of the aquatic insect populations within the two parks.

ii) The effects of wildlife herbivory on riparian areas and watersheds have received only anecdotal or incidental attention on the literature (Schepers ad Francis 1982). Moreover, just one published study has directly examined the relationship between livestock herbivory and aquatic insects (Rinne 1988), while no studies are available on the influence of wildlife herbivory on stream insects.

iii) The results from the study will contribute to the debate on the terrestrial and aquatic factors responsible for 
structuring the aquatic insect community. Specifically, the study will address the validity of the River Continuum Concept, an hypothesis concerning the relationship between stream and terrestrial habitats which has received both support (Minshall 1983) and criticism (e.g., Hawkins et. al. 1982, Statzner and Higler 1986, Townsend 1989 ) in the literature.

iv) Given that livestock grazing constitutes the most ubiquitous land practice in the eleven western states, it is important to gain a better understanding of how grazing and browsing activities affect riparian areas, not only in terms of the possible effects on the aquatic insects, but also in relation to the productivity of game fish populations which rely on the insects as primary source of food.

v) Lastly, the findings from the study will address the broader issue of whether and by what means the wildlife management paradigm of the Park Service, which has undergone substantial revisions over the years, affects riparian and stream areas within the Grand Teton and Yellowstone National Parks. That is, does the manner in which the Park Service manages the elk and moose populations influence the condition of riparian and stream habitats within the two parks?

To elaborate on the fifth point, the Park Service presently manages the Greater Yellowstone Ecosystem under the natural regulation paradigm, a largely laissez-faire form of management which holds that most undisturbed wildlife populations exist in an equilibrium with their environment, with conceivably either acting as a positive or negative feedback upon the other. Proponents of this management scheme generally consider the amount of winter forage to be the most significant element involved in the regulation of ungulate populations (Coughenour and Singer 1991). The corollary to these suppositions is that the wildlife will not permanently alter the conditions of its environment beyond some equilibrium state (for dissent to the equilibrium component of this view see Boyce 1989).

Chadde and Kay (1991) and Beetle (1979) examined various tree-shrub communities within
Yellowstone and Jackson Hole and found that, in apparent contradiction to the natural regulation paradigm, elk browsing had eliminated or reduced the presence of some plant species such as willow and aspen, the loss of which, they submit, explains the decline of beaver, white-tailed deer, native trout species, and even grizzly bears. Chadde and Kay (1991) concluded that the population of elk within the Greater Yellowstone Ecosystem has come to exceed historical levels (due to human interference), and thus the natural regulation paradigm has little relevance for present conditions in the two parks. Houston (1982), though, examined the condition of vegetation within Yellowstone and asserted from a review of this data that the elk population seemingly falls within the natural carrying capacity of the park. The study attributed the loss of aspen to the suppression of fire and claimed that the intense browsing of some plant communities results from a natural interaction between herbivores and plants (Caughley 1976).

It is important to stress that this study will not provide results with which to evaluate the legitimacy of the natural regulation paradigm. Rather the study will concern how wildlife herbivory affects riparian and stream habitats, irrespective of whether such browsing is considered a natural consequence of herbivore-plant interactions or an unnatural result of a mismanaged elk herd. Ultimately, the findings from this study should prove interesting to researchers on either side of the issue.

\section{$\downarrow \quad$ METHODS}

\section{SITE SELECTION}

Three general categories, each comprising three streams, will be used to distinguish the different grazing and browsing intensities among the sites; no/minimal herbivore use, moderate herbivore use, and heavy herbivore use. Nine first-order streams have been identified as exhibiting similar substrate composition (cobble/rock), natural disturbance regimes (very high flows during spring snow melt), alkalinity and hardness (low alkalinity and soft water), and bank soil composition (suitable for shrub growth). The flow rates of the streams differ and thus the sites have been stratified for the sake of statistical analysis according to this variable, 
albeit imperfectly, since it proved infeasible to match stream flows precisely (Table 1).

\begin{tabular}{|c|c|c|c|}
\hline Flow & $\begin{array}{l}\text { Minimal } \\
\text { Herbivore Use }\end{array}$ & $\begin{array}{l}\text { Moderate } \\
\text { Herbivore Use }\end{array}$ & $\begin{array}{l}\text { Heavy } \\
\text { Herbivore Use }\end{array}$ \\
\hline Low & $\begin{array}{l}\text { Cache Creek } \\
\text { Bridger-Teton } \\
\text { Forest }\end{array}$ & $\begin{array}{l}\text { Coffman Creek, } \\
\text { Grand Teton } \\
\text { Park }\end{array}$ & $\begin{array}{l}\text { Flat Creek } \\
\text { National Elk } \\
\text { Refuge }\end{array}$ \\
\hline Medium & $\begin{array}{l}\text { Lake Creek, } \\
\text { Grand Teton } \\
\text { Park }\end{array}$ & $\begin{array}{l}\text { Little Granite } \\
\text { Creek, Bridger- } \\
\text { Teton Forest }\end{array}$ & $\begin{array}{l}\text { Blacktail Deer } \\
\text { Creek, } \\
\text { Yellowstone } \\
\text { Park }\end{array}$ \\
\hline High & $\begin{array}{l}\text { Cottonwood } \\
\text { Creek, Grand } \\
\text { Teton Park }\end{array}$ & $\begin{array}{l}\text { Granite Creek } \\
\text { Grand Teton } \\
\text { Park }\end{array}$ & $\begin{array}{l}\text { Soda Butte } \\
\text { Creek, } \\
\text { Yellowstone } \\
\text { Park }\end{array}$ \\
\hline
\end{tabular}

The quantitative evaluation of grazing and browsing intensity is generally characterized by the presence of comparatively dense, unforaged riparian vegetation indicative of minimal browsing activity. The three moderately browsed sites are characterized by riparian areas with shrubs lining most of the streams and with a few well-worn paths, formed by the wildlife, cutting through the banks. The shrubs exhibit a uniform horizontal graze line which rises from 3 to 6 feet in height. The shrubs of the heavily grazed streams have been browsed to a height of less than one foot and are far less abundant than those at the minimally or moderately browsed sites. Along considerable portions of the heavily browsed streams, some species of riparian vegetation have been removed completely or persist exclusively in a late succession phase, that is, denuded of shrubs with only mature trees lining the banks. In addition, archival photographic evidence from the late 1800 s exists for two of the heavily grazed sites in Yellowstone which will afford a temporal comparison of riparian conditions.

\section{MACROINVERTEBRATE SAMPLING}

Macroinvertebrate samples will be collected with a modified Hess sampler as described by Mackay and Kalff (1969). Nine samples were collected in August and October of 1996 from riffle areas within each of the nine streams. Sampling will be repeated at the same times in 1997. Identification will be performed to the lowest possible taxonomic level.
Diversity indices, including the ShannonWeaver Index, similarity coefficients, and Tolerance Quotients, will be used to compare the macroinvertebrate communities. In addition, the macroinvertebrates will be partitioned according to functional feeding categories (i.e., percent of samples comprised of shredders, scrapers, collectorgatherers, collector-filterers, and predators) as established by Merritt and Cummins(1984).

\section{ENVIRONMENTAL VARIABLES}

Within each control and treatment reach, a series of transects will be placed at regular intervals (about $3 \mathrm{~m}$ ) along the sampling area for the evaluation of riparian and stream variables in accordance with the methods of Platts et.al. (1987) and Platts and Nelson (1985). The environmental variables to be measured include percent of pools, substrate composition, embeddedness, bank stability, canopy, channel width:depth, and streamside forage use. Also, benthic core samples will be collected in immediate proximity to the insect samples so as to determine the amount of benthic organic matter (Hawkins et. al. 1982).

Water quality measurements will be taken along with each macroinvertebrate sample and processed according to Standard Methods (APHA 1995). Velocity will be measured using a current meter at each macroinvertebrate sampling site. Algal standing crops will be evaluated through the placement of artificial glass substrates into riffle areas as described by Meier et. al. (1983), which will be analyzed for ash-free dry matter, chlorophyll $a$, and composition of algal species.

\section{STATISTICS}

Parametric and nonparametric statistics will be used in the evaluation of the continuous and noncontinuous data, respectively. Multivariate analyses (PCA and DCA) will be performed to differentiate the sites based on physical, chemical, and biotic variables. In addition, Canonical Correlation Analysis will be used to relate the distribution of the environmental variables to the biotic variables (Neter, 1990). 


\section{PRELIMINARY RESULTS}

In August and October of 1996, benthos and water samples were collected from all nine sites. The macroinvertebrates from these samples have been isolated from the benthos debris but not yet completely identified to genus or species level. Nonetheless, it appears evident from an initial survey of the samples that the three streams subject to heavy herbivore utilization support an insect assemblage dominated by ephemeropterans, an order for which the majority of species belong to the functional feeding groups of scrapers or collectorgatherers. The moderately grazed streams and the control streams seem to harbor a greater diversity of species, particularly of trichopterans and tipulids, and to support a more diverse trophic structure. The trichopterans in fact comprise the majority of species, both by biomass and numbers, within the control streams and constitute a much larger component of the benthic community within the moderately grazed streams than at the heavily grazed sites. The densities of insects appear to be rather uniform among the different browsing treatments with greater numbers possibly existing at two of the moderately browsed sites. In terms of available food resources, the chlorophyll $a$ and biomass of periphyton collected from glass slides from the heavily grazed sites do not differ significantly from that of the moderately grazed sites or even the control sites ( $p>.1$, ANOVA). Within the heavily grazed streams, however, woody debris and leaf material are for the most part absent from benthic core samples, whereas within the moderately and lightly grazed sites allochthonous matter forms a substantial component of the benthic material. These observations suggest that wildlife herbivory, by altering the condition of riparian vegetation, also affects the composition of the aquatic biota.

\section{CONCLUSION}

The principal question to be addressed in this study is whether the effects of wildlife herbivory within riparian areas influence the structure of the aquatic macroinvertebrate community. The research entails measuring both riparian and in-stream variables in an attempt to quantify the effects of herbivory with the purpose of relating these effects to the indices used to characterize the aquatic insects. If the research goals of this proposal are fulfilled, the study will succeed in contributing to an understanding of stream ecology and wildlife management and lead to an appreciation of how these two spheres interact within the Greater Yellowstone Ecosystem.

\section{$\downarrow \quad$ Literature Cited}

American Public Health Association. 1995. Standard Methods for the Examination of Water and Wastewater. APHA, Washington, D.C.

Beetle, A.A. 1979. Jackson Hole elk herd. In: M.S. Boyce and C.D. Hayden-Wing (eds.). North American Elk: 257:262. University of Wyoming Press, Laramie, Wyoming.

Bisson, P.A., and G.E. Davis. 1976. Production of juvenile chinook salmon in a heated model stream. U.S. National Marine Fisheries Service Fishery Bulletin 74:763774.

Boyce, M.S. 1989. The Jackson Elk Herd. Cambridge University Press, New York.

Caughley, G. 1976. Wildlife management and the dynamics of ungulate populations. $\underline{\text { In: }}$ T.H. Croaker (ed.). Applied Biology, v. 1:183-246. Academic Press, London.

Chadde, S.W. and C.E. Kay. 1991. Tall-willow communities on Yellowstone's Northern Range. In: R.B. Keiter and M.S. Boyce (eds.). The Greater Yellowstone Ecosystem: 231-262. Yale University Press, New Haven, Connecticut.

Coughenour, M.B. and F.J. Singer. 1991. The concept of overgrazing and its application to Yellowstone's Northern Range. In: R.B. Keiter and M.S. Boyce (eds.). The Greater Yellowstone Ecosystem: 209-230. Yale University Press, New Haven, Connecticut.

Despain, D.G. 1989. Interpretation of exclosures in riparian vegetation. In: R.E. Greswell (ed.). Practical Approaches to Riparian Resource Management:757. U.S. Bureau of Land Management. Billings, Montana. 
DeWalt, E.R., and K.W. Stewart. 1995. Life histories of stoneflies in the Rio Canejos of southern Colorado. Great Basin Naturalist 55(1):1-18.

Dudgeon, D. 1988. The influence of riparian vegetation on macroinvertebrate community structure in four Hong Kong streams. Journal of Zoology 216:609-627.

Hawkins, C.P., M.L. Murphy, and N.H. Anderson. 1982. Effects of canopy, substrate composition, and gradient on the structure of macroinvertebrate communities in Cascade range streams of Oregon. Ecology 63(6):1840-1856.

Houston, D.B. 1982. The Northern Yellowstone Elk. Macmillam Publishing Co., New York.

Lenat, D.R., D.L. Penrose, and K.W. Eagleson. 1981. Variable effects of sediment addition on stream benthos. Hydrobiologia 79:187194.

Li, H.W., G.A. Lamberti, T.N. Pearsons, C.K. Tait, J.L. Li, and J.C. Buckhouse. 1994. Cumulative effects of riparian disturbances along high desert trout streams of the John Day Basin, Oregon. Transactions of the American Fisheries Society 123:627-640.

Mackay, R.J., and J. Kalff. 1969. Seasonal variation in standing crop and species diversity of insect communities in a small Quebec stream. Ecology 50:101-109.

Meier, P.G., D.O;Connor, and D. Dilks. 1983. Artificial substrata for reducing periphytic variability on replicated samples. In: R.G. Wetzel (ed.). Periphyton of Freshwater Ecosystems. Dr. W. Junk Publishers. The Hague.

Merritt, R.W., and K.W. Cummins (eds.). 1984. An Introduction to the Aquatic Insects (2nd ed.). Kendall/Hunt Publishing. Dubuque, Iowa.

Minshall, G.W. 1984. Aquatic insect-substratum relationships. In: V.H. Resh and D.M. Rosenberg (eds.). The Ecology of Aquatic Insects: 358-400. Praeger, New York.
Minshall, G.W. 1983. Interbiome comparison of stream ecosystem dynamics. Ecological Monographs 13:1-25.

Minshall, G.W., and J.N. Minshall. 1977. Microdistribution macroinvertebrates in a Rocky Mountain stream. Hydrobiologia 55:231-249.

Murphy, M.L., C.P. Hawkins, and N.H. Anderson. 1981. Effects of canopy modification and accumulated sediment on stream communities. Transactions of the North American Fisheries Society 110:469-478.

Myers, T.J. and S. Swanson. 1995. Impact of deferred rotation grazing on stream characteristics in central Nevada: A case study. North American Journal of Fisheries Management 15:428-439.

Neter, J. 1990. Applied Linear Statistical Models. 3rd ed. Irwin. Homewood, IL.

Platts, W.S., and R.L. Nelson. 1985. Impacts of rest-rotation grazing on stream banks in forested watersheds in Idaho. North American Journal of Fisheries Management 5:547-556.

Platts, W.S., et.al.. 1987. Methods for Evaluating Riparian Habitats with Applications to Management. US Forest Service Gen. Tech. Rep. INT.-221, Ogden, Utah.

Rinne, J.N. 1988. Effects of livestock grazing exclosure on aquatic macroinvertebrates in a montane stream, New Mexico. Great Basin Naturalist 48(2):146-153.

Schepers, J.S., and D.D. Francis. 1982. Chemical water quality of runoff from grazing in Nebraska: Influence of grazing livestock. Journal of Environmental Quality 11(3):351-354.

Smith, M.A., J.L. Dodd, and P. Meiman. 1994 (unpublished). Effects of domestic livestock and wildlife grazing in Grand Teton National Park. University of Wyoming, Laramie, Wyoming. 
Statzner, B., and B. Higler. 1986. Stream hydraulics as a major determinant of benthic zonation patterns. Freshwater Biology 16:127-139.

Townsend, C.R. 1989. The patch dynamics concept of stream community ecology. Journal of the North American Benthological Society 8:36-50.

Wesche, T.A., C.M. Goertler, and C.B. Frye. 1987. Contribution of riparian vegetation to trout cover in small streams. North American Journal of Fisheries Management 7:151-153. 